\title{
PENINGKATAN HASIL BELAJAR PKn SISWA \\ KELAS VI SD 3 JEKULO KUDUS MELALUI \\ MODEL PROBLEM BASED LEARNING
}

\author{
Santoso, Ika Oktavianti \\ Email sentosa_mpd@yahoo.co.id, \\ Prodi Pendidikan Guru Sekolah Dasar \\ Fakultas Keguruan dan Ilmu Pendidikan \\ Universitas Muria Kudus
}

\begin{abstract}
This research is to increase the result of study of civic education taught by using problem based learning. Problem based learning is learning with the students problem practical as based on the study or the students study taught their problem. The students in this model are must to active to solve a problem.the result of study is change of the student behaviour based on cognitif, afective and psikomotoric after teaching and learning process. The action of hypothesis is the result of study civic education taught by using Problem Based Learning of the sixth grade students of SD 3 Jekulo Kudus can be increase.

This research is classroom action research in the sixth grade students of SD 3 Jekulo Kudus with the subject of the research is 20 students with 2 cycles, every cycle contains two meetings. Independent Variable of the reasearch is Problem Based Learning, dependent variable is the result of study of civic education. In collecting the data using interview, notes, observation, test and documentation. Analyze the data by using qualitative and quantitative.

The result of this research showed that Problem Based Learning can increase the result of civic education. This result can see from the indicator. The percentage of the result study of cognitive test evaluation from cycle 1 is $60 \%$ increase $85 \%$, then cycle 2 with the average class cycle I 75,75 become 80.50 .The result study of afective in cycle 1 is 67 , the qualification is good become 82 in cycle II the qualification is good. The result of study of psikomotoric of cycle I is $60 \%$ with qualification is good become $85 \%$ with qualification is good in cycle II.

The conclusion of this research is Problem Based Learning can be increase the result study of civic education of the sixth grade students of SD 3 Jekulo Kudus. The suggesstion of this research is, the students must be active and add positive study to get good result of study. For the teacher, should be plan model of learning and media can be increase the students participation in teaching and learning process.
\end{abstract}

Key words : The result of study Civic Education, Problem Based Learning

\begin{abstract}
ABSTRAK
Penelitian ini bertujuan untuk meningkatkan hasil belajar siswa pada mata pelajaran PKn melalui model Problem Based Learning. Model Problem Based Learning merupakan pembelajaran dengan mengahadapkan siswa pada permasalahan-permasalahan praktis sebagai pijakan dalam belajar atau dengan kata lain siswa belajar melalui masalah. Siswa dalam model ini dituntut untuk aktif memecahkan suatu masalah. Hasil belajar adalah perubahan tingkah laku siswa yang dilihat dari aspek kognitif, afektif, maupun psikomotorik setelah mengikuti pembelajaran. Hipotesis tindakan yang diajukan adalah hasil belajar PKn melalui model Problem Based Learning siswa kelas VI SD 3 Jekulo Kudus dapat meningkat.

Penelitian ini merupakan penelitian tindakan kelas yang dilaksanakan di kelas VI SD 3 Jekulo Kudus dengan subjek penelitian 20 siswa yang berlangsung selama dua siklus masingmasing siklus terdiri dari dua pertemuan. Variabel bebas dalam penelitian ini adalah model Problem Based Learning, sedangkan variabel terikatnya yaitu hasil belajar PKn. Metode pengumpulan data berupa wawancara, observasi, tes, catatan lapangan, dan dokumentasi. Data yang diperoleh dari tindakan yang dilakukan dianalisis secara kuantitatif dan kualitatif.

Hasil penelitian menunjukkan bahwa melalui model Problem Based Learning dapat meningkatkan hasil belajar PKn. Hal ini dapat dilihat dari tercapinya indikator keberhasilan sebagai berikut. Persentase ketuntasan hasil belajar klasikal pada ranah kognitif tes evaluasi siklus I 60\% meningkat menjadi $85 \%$ pada tes evaluasi siklus II dengan peningkatan nilai rata-rata kelas pada siklus I 75,75 menjadi 80,50 pada siklus II. Hasil belajar siswa pada ranah afektif pada siklus I ratarata memperoleh nilai $67 \%$ dengan kualifikasi "baik" meningkat pada siklus II menjadi 82 dengan
\end{abstract}


kualifikasi "baik". Hasil belajar siswa pada ranah psikomotorik pada siklus I rata-rata memperoleh nilai $60 \%$ dengan kualifikasi "baik" meningkat pada siklus II menjadi $85 \%$ dengan kualifikasi "sangat baik

Simpulan dalam penelitian ini yaitu melalui model Problem Based Learning dapat meningkatkan hasil belajar PKn siswa kelas VI SD 3 Jekulo Kudus. Saran dalam penelitian ini, siswa hendaknya aktif dan menumbuhkan sikap positif dalam belajar agar dapat meraih hasil belajar yang baik. Bagi guru, hendaknya merencanakan model pembelajaran dan media yang dapat meningkatkan partisipasi siswa dalam kegiatan pembelajaran.

\section{Kata Kunci: Hasil Belajar PKn, Problem Based Learning}

\section{Pendahuluan}

Pendidikan Kewarganegaraan memiliki tujuan untuk membentuk perilaku warga Negara yang memiliki kepribadian sesuai dengan nilai-nilai karakter budaya bangsa Indonesia. Upaya untuk mewujudkan tujuan tersebut, pendidikan memiliki peran yang sangat penting. Pendidikan adalah kegiatan yang dilakukan secara terstruktur antara guru dengan siswa dalam kegiatan pembelajaran di sekolah. Salah satu mata pelajaran di sekolah dasar yang memiliki peran penting dalam pembentukan watak atau karakteristik warga negara yang baik yang baik yaitu mata pelajaran PKn.

Menurut Permendiknas No 22 tentang Standar isi bahwa Pendidikan Kewarganegaraan seharusnya bukan hanya menyampaikan konsep-konsep pengetahuan semata, akan tetapi juga harus dapat membimbing peserta didik menjadi warga masyarakat yang memiliki tanggung jawab, pahamakan hak dan kewajibannya sebagai warga negara yang baik serta dapat berfikir secara rasional, kritis, dan kreatif serta dapat ikut serta menempatkan diri berperan menanggapi persoalan hidup di negaranya. Akan tetapi, dalam implementasi sering kita jumpai proses penyampaian konsep tersebut lebih diarahkan pada kemampuan peserta didik untuk menghafal segala informasi yang diterima. Artinya peserta didik hanya diberikan konsep-konsep pengetahuan semata tanpa dibimbing untuk mengembangkan potensi agar menjadi manusia yang lebih rasional, kritis dan kreatif sesuai dengan tujuan pendidikan tersebut.

Implementasi dunia pendidikan kita tidak sepenuhnya berbanding lurus dengan teori ataupun tujuan pendidikan yang diharapkan. Proses pembelajaran atau penyampaian informasi lebih banyak disampaikan melalui metode konvensional. Dalam proses pembelajaran konvensional, penyampaian informasi sering hanya berpusat pada guru, dan siswa hanya pasif menerima informasi yang disampaikan guru. Hal seperti ini selaras dengan ungkapan Rusmono (2012: 2) yang menyatakan bahwa "aktivitas yang terjadi di kelas umumnya masih menempatkan guru sebagai satu-satunya sumber informasi yang dapat membuat siswa menjadi bertambah pengetahuannya". Proses belajar yang demikian adanya masih mendominasi sekolah-sekolah di negara kita ini meskipun sebagian kecil anakanak usia pendidikan dasar dan menengah mampu meraih olimpiade. Akan tetapi, yang menjadi sorotan utama adalah banyak para pendidik di negara kita ini di berbagai jenjang pendidikan dasar dan menengah yang mengelola kelasnya hanya dengan satu arah sehingga interaksi guru ke siswa atau ke siswa lain tidak maksimal. Cara belajar siswa pun sering didominasi dengan cara metode menghafal sehingga pembelajarannya hanya teoritis dan abstrak yang mengakibatkan pembelajaran kurang bermakna dan berkesan bagi siswa. Pembelajaran yang seperti ini dapat mengakibatkan motivasi dan keaktivan siswa menurun dan hasil belajar siswa tidak dapat tercapai dengan maksimal.

Kegiatan pembelajaran pada siswa kelas VI SD 3 Jekulo Kudus masih kurang maksimal. Hal ini terlihat dari observasi awal yang dilakukan peneliti terhadap kegiatan pembelajaran pada mata pelajaran PKn di SD 3 Jekulo, proses belajar mengajar cenderung guru lebih dominan dari pada siswa. Siswa hanya duduk diam mendengarkan penjelasan dari guru. Siswa di suruh mendengarkan dan mengerjakan lembar kerja siswa. Kondisi kegiatan belajar mengajar yang demikian masih kurang efektif untuk meningkatkan hasil belajar siswa,

Kondisi pembelajaran yang demikian menyebabkan hasil belajar PKn pada siswa kelas VI di SD 3 Jekulo menjadi kurang maksimal. Hal tersebut terlihat dari KKM (Kriteria Ketuntasan Minimal) untuk mata pelajaran PKn yaitu 75 dan masih ada beberapa siswa yang belum mencapai KKM. Berdasarkan nilai ulangan yang peneliti peroleh, siswa yang sudah mencapai KKM 
berjumlah 8 dari 20 siswa dan siswa yang belum mencapai KKM berjumlah 12 dari 20 siswa. Dari hasil tersebut terlihat bahwa dengan proses belajar yang demikian menyebabkan hasil belajar siswa SD 3 Jekulo kurang maksimal.

Pembelajaran pada mata pelajaran PKn di SD 3 Jekulo ini hanya menekankan pada aspek kognitif saja. Padahal seharusnya guru harus dapat menanamkan 3 aspek kemampuan yang utama yakni aspek afektif, aspek kognitif, dan aspek psikomotorik dalam setiap proses pembelajaran. Sebagaimana yang diungkapkan oleh Sudjana (2010:49) yang menyatakan bahwa ketiga aspek (kognitif, afektif, psikomotorik) tersebut tidak dapat berdiri sendiri, tapi merupakan satu kesatuan yang tidak terpisahkan bahkan membentuk hirarki. Sebagai tujuan yang hendak dicapai, ketiga aspek tersebut harus dipandang sebagai hasil belajar siswa dari proses pengajaran.

Sanjaya (2011:137) juga menyatakan bahwa dalam proses pembelajaran yang berorientasi siswa aktif, hasil belajar hendaknya seimbang dan terpadu antara kemampuan intelektual (kognitif), sikap (afektif) dan keterampilan (psikomotorik), pembentukan siswa secara utuh merupakan tujuan utama dalam proses pembelajaran. Untuk itu, keseimbangan antara ketiga aspek tersebut mutlak diperlukan agar peserta didik bukan hanya cerdas secara intelektual akan tetapi diimbangi oleh sikap dan ketrampilan yang baik. Hal tersebut agar berbanding lurus dengan tujuan pendidikan nasional yang bukan hanya membentuk manusia cerdas akan tetapi juga membentuk manusia yang bertaqwa dan memiliki ketrampilan disamping memiliki sikap budi pekerti yang luhur.

Solusi yang dapat diberikan dalam menangani permasalahan tersebut adalah dengan melakukan Penelitian Tindakan Kelas dengan menerapkan model pembelajaran Problem Based Learning. Model pembelajaran problem based learning (pembelajaran berdasarkan masalah) dirasa dapat memberikan suasana yang baru yang inovatif dalam proses pembelajaran. Dengan menggunakan model pembelajaran problem based learning menghadapkan siswa pada permasalahanpermasalahan praktis sebagai pijakan dalam belajar atau dengan kata lain siswa belajar dengan permasalahan-permasalahan. Sehingga siswa diharapkan mampu untuk berpikir kritis mengenai proses pembelajaran dan mampu untuk meningkatkan hasil belajar mata pelajaran PKn.

Model pembelajaran problem based learning dirasa cukup relevan dan mampu untuk dikembangkan menjadi model pembelajaran yang lebih baik. Karena pada dasarnya dalam mata pelajaran PKn itu tidak hanya cukup hanya dengan hafalan, dan mendengarkan materi yang disampaikan oleh guru, akan tetapi siswa perlu memahami dan bisa melaksanakan nilai-nilai positif dalam kehidupan sehari-hari.

Berdasarkan uraian tersebut, peneliti melakukan penelitian tindakan kelas yang berjudul "Peningkatan Hasil Belajar PKn siswa Kelas VI SD 3 Jekulo Kudus Melalui Model Problem Based Learning".

Metode Penelitian

Penelitian tindakan kelas ini dilaksanakan di SD 3 Jekulo Kabupaten Kudus, dengan subjek dalam penelitian ini adalah siswa Kelas VI semester satu yang berjumlah 20 siswa. Fokus penelitian pada hasil belajar siswa pada pembelajaran PKn. Jenis penelitian yang digunakan adalah penelitian tindakan kelas. Menurut Kurt Lewin, prosedur kerja dalam penelitian tindakan kelas terdiri atas empat komponen, yaitu perencanaan (planning), pelaksanaan (acting), pengamatan (observing), dan refleksi (reflecting). Hubungan keempat komponen tersebut dipandang sebagai satu siklus.

Untuk memperoleh data yang benar dan akurat dalam penelitian ini, maka peneliti menggunakan beberapa metode yang antara lain: 1) observasi partisipatif, 2) metode pengukuran hasil tes, 3) metode dokumentasi. Analisis yang digunakan dalam penelitian tindakan kelas ini adalah teknik analisis deskriptif dengan menentukan persentase ketuntasan belajar dan mean (rata-rata) kelas.

\section{Hasil Penelitian dan Pembahasan}

Hasil penelitian pada siswa kelas VI di SD 3 Jekulo Kabupaten Kudus menunjukan adanya peningkatan hasil belajar siswa. Hasil belajar yang mengalami peningkatan diantaranya pada aspek kognitif, afektif dan psikomotorik. Ranah afektif dan psikomorik disini terlihat pada hasil lembar observasi keaktivan siswa. Melalui model pembelajaran problem based learning dapat meningkatkan keaktivan dan hasil belajar siswa. Adapun peningkatan aktivitas siswa baik afektif maupun psikomotorik dapat dilihat pada gambar di bawah ini. 


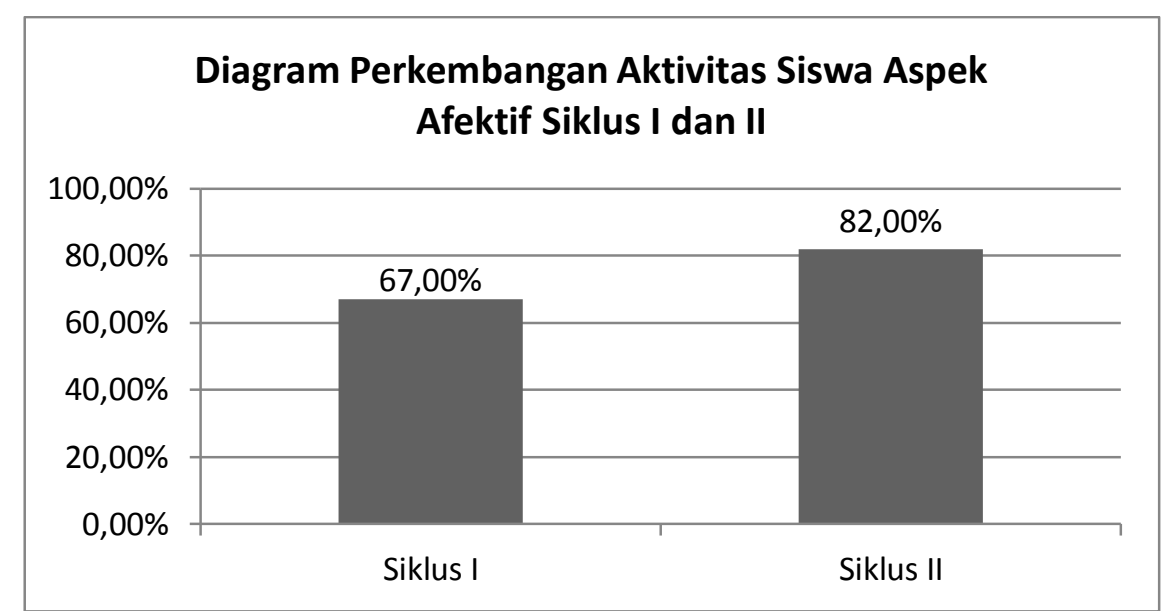

Gambar 1. Diagram hasil pengamatan aktivitas ranah afektif siswa pada siklus I dan siklus II.

Berdasarkan diagram 1 terlihat bahwa persentase aktivitas siswa aspek afektif pada siklus I sebesar $67.00 \%$ sedangkan pada siklus II sebesar $82.00 \%$. Diketahui bahwa persentase aktivitas siswa aspek afektif dari siklus I ke

siklus II mengalami peningkatan sebesar $15,00 \%$. Adapun peningkatan aktivitas siswa aspek psikomotorik dapat dilihat pada gambar di bawah ini.

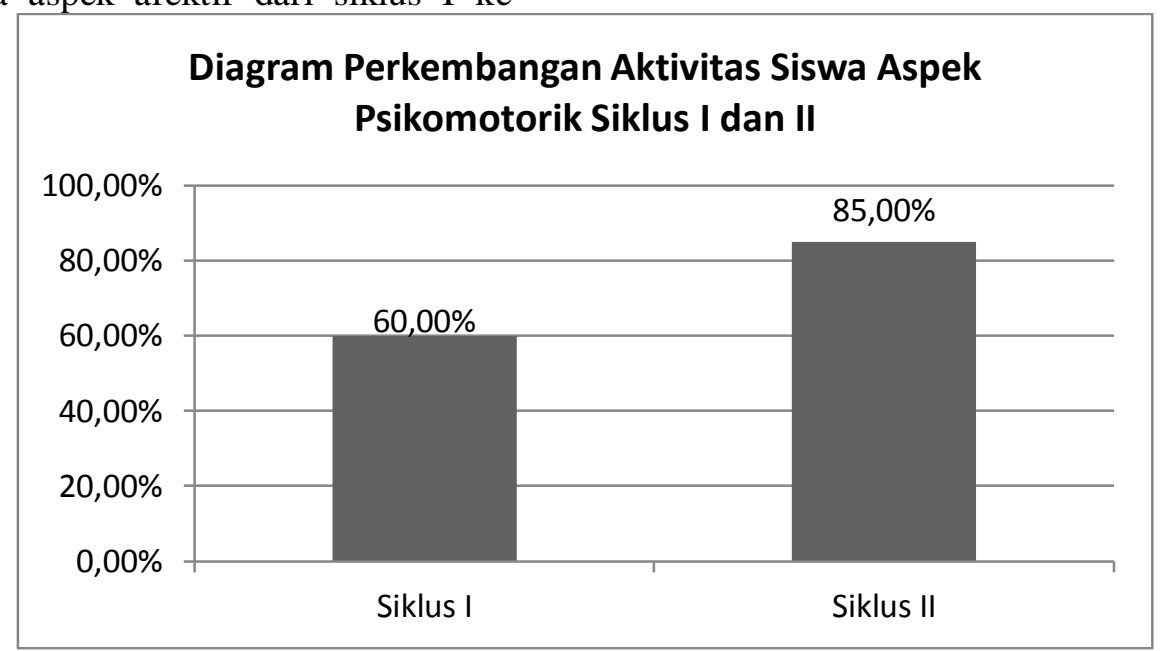

Gambar 2. Diagram hasil pengamatan aktivitas ranah psikomotorik siswa pada siklus I dan siklus II.

Berdasarkan diagram 2 terlihat bahwa persentase aktivitas siswa aspek psikomotorik pada siklus I sebesar $60.00 \%$ sedangkan pada siklus II sebesar $85.00 \%$. Diketahui bahwa persentase aktivitas siswa aspek psikomotorik

dari siklus I ke siklus II mengalami peningkatan sebesar 25,00\%. Adapun peningkatan ketuntasan hasil belajar siswa secara klasikal dari pra siklus, siklus I dan siklus II.

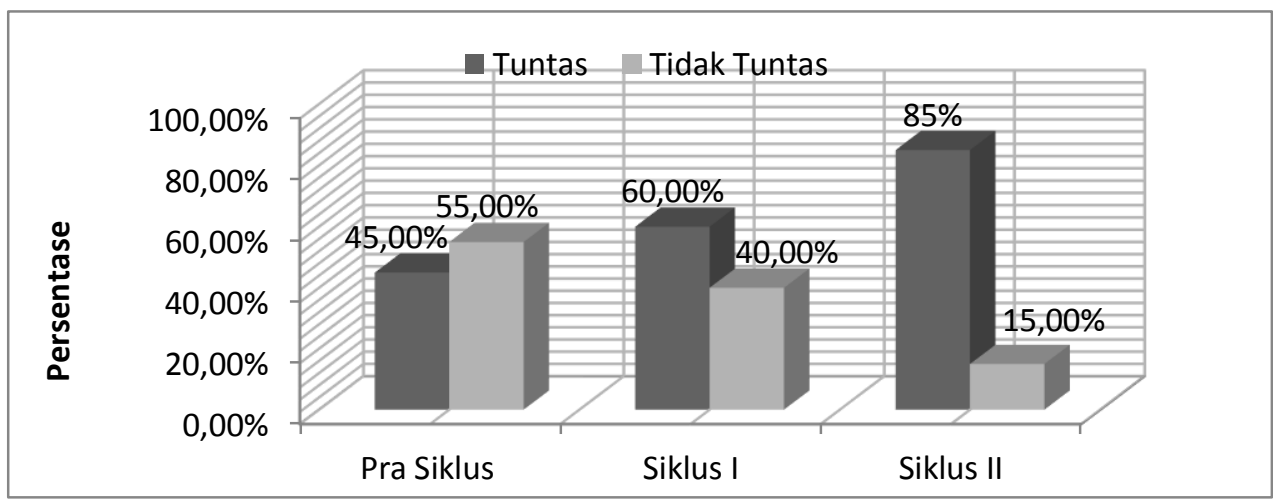

Gambar 3. Diagram hasil evaluasi ranah kognitif siswa pada pra siklus, siklus I dan siklus II. 
Berdasarkan diagram tiga di atas bahwa hasil belajar siswa pada kelas VI di SD 3 Jekulo Kudus mengalami peningkatan. Pada pra siklus siswa yang tuntas $45 \%$ dan siswa yang tidak tuntas 55\%, siklus I siswa yang tuntas $60 \%$ dan siswa yang tidak tuntas $40 \%$ dan siklus II siswa yang tuntas $85 \%$ dan siswa yang tidak tuntas $15 \%$. Dengan demikian, sudah memenuhi indikator keberhasilan yaitu $75 \%$ siswa mengalami ketuntasan belajar individual sebesar $\geq 75$ dalam pembelajaran PKn.

Perbandingan rata-rata nilai keaktivan siswa pada ranah afektif dalam kelas baik siklus I ataupun siklus II mengalami peningkatan. Pada siklus I rata-rata $67 \%$ kemudian meningkat pada siklus II menjadi $82 \%$. Dalam siklus I masih ada siswa yang belum mengikuti pembelajaran secara aktif, hal ini dikarenakan siswa masih terbiasa dengan pembelajaran konvensional. Pada siklus II siswa sudah terbiasa mengikuti pembelajaran yang variatif menggunakan model pembelajaran problem based learning. Walaupun ada salah satu siswa yang kurang respon terhadap pembelajaran, sehingga konsentrasi pembelajaran kadang masih ramai.

Aktivitas siswa pada ranah psikomotorik mengalami meningkatan sejalan dengan aktivitas siswa pada ranah afektif dan kognitif. Menurut Bloom (Suprijono, 2013:6). "Hasil belajar mencakup kemampuan kognitif, afektif dan psikomotorik". Dari hasil penelitian ini kemampuan siswa pada ranah kognitif yaitu siswa mampu mengetahui materi tentang kegiatan pilkada yang biasanya diselenggarakan oleh KPUD setiap lima tahun sekali. Kemampuan siswa pada ranah afektif ditunjukkan dengan kemampuan dalam menerima pendapat dari orang atau perbedaan yang di timbulkan dari adanya kegiatan Pilkada pada saat diskusi kelompok. Sedangkan kemampuan ranah psikomotorik siswa dapat ditunjukkan dengan adanya kegiatan orasi di depan kelas dan produk lembar kerja siswa tentang permasalahan yang terjadi akibat dari kegiatan Pilkada.

Hasil penelitian yang sudah dipaparkan diatas terbukti berhasil dikarenakan hipotesis terjawab, yaitu Penerapan Model Pembelajaran problem based learning dapat Meningkatkan hasil belajar siswa pada mata pelajaran PKn siswa kelas VI di SD 3 Jekulo Kabupaten Kudus. Dengan indikator keberhasilan yang terpenuhi semua, yaitu rata- rata hasil belajar kognitif meningkat dari 75,75 siklus I menjadi 80,05 pada siklus II. Hasil belajar afektif meningkat dari siklus I yang mendapat nilai rata-rata 67 menjadi 82 pada siklus II. Sedangkan hasil belajar psikomotorik meningkat dari $60 \%$ pada siklus I menjadi $85 \%$ pada siklus II.

\section{Simpulan}

Berdasarkan hasil penelitian dan pembahasan terhadap peningkatan hasil belajar siswa pada mata pelajaran PKn kelas VI di SD 3 Jekulo Kabupaten Kudus melalui model problem based learning, maka peneliti menarik kesimpulan bahwa penerapan model problem based learning dapat meningkatkan hasil belajar PKn pada siswa kelas VI SD 3 Jekulo. Aktivitas siswa pada aspek afektif pada siklus I diperoleh rata-rata nilai sebesar $67 \%$ dengan kualifikasi "baik" dan pada siklus II mengalami peningkatan menjadi $82 \%$ dengan kualifikasi "baik". Aktivitas siswa aspek psikomotorik pada siklus I diperoleh rata-rata nilai sebesar $60 \%$ dengan kualifikasi "baik" dan pada siklus II mengalami peningkatan menjadi $85 \%$ dengan kriteria "sangat baik".

Hasil belajar kognitif siswa meningkat dari pra siklus, siklus I, dan siklus II. Rata-rata klasikal hasil belajar kognitif pra siklus yaitu 60 dan ketuntasan klasikal 45\% dengan kriteria "sedang", rata-rata ketuntasan klasikal pada siklus I yaitu 75,75, dan ketuntasan klasikal $60 \%$ dengan kriteria "tinggi", rata-rata klasikal pada siklus II yaitu 80,50 dan ketuntasan klasikal 85\% dengan kriteria "sangat tinggi"

Berdasarkan simpulan di atas, maka saran yang diharapkan, antara lain: (1) Bagi guru SD, guru hendaknya memberikan pembelajaran dengan menerapkan model-model yang berpusat pada siswa (Student Centered Learning). Problem Based Learning dapat menjadi salah satu alternatif model pembelajaran yang dapat diterapkan dalam mata pelajaran PKn. (2) Bagi siswa, siswa hendaknya aktif dalam pembelajaran. Selain itu, kerjasama diantara siswa dalam kelompok perlu ditingkatkan karena suatu masalah lebih mudah dipecahkan jika diselesaikan secara kelompok. (3) Bagi peneliti, diharapkan dapat mengembangkan penelitian dengan model pembelajaran yang lain, sehingga dapat menemukan solusi pemecahan baru dalam mengembangkan pembelajaran dan meningkatkan hasil pembelajaran di kelas.

\section{DAFTAR PUSTAKA}

Amir, Taufiq, 2009. Inovasi pendidikan problem based learning. Jakarta: Kencana 
Aqib, Zainal. 2010. Penelitian Tindakan Kelas. Bandung: CV Krama Widya.

Aqib, Zainal, 2002. Profesionalisme Guru Dalam Mengajar. Surabaya: Insan Cendikia.

Arikunto, Suharsimi. 2006. Prosedur Penelitian Suatu Pendekatan Praktik. Jakarta: Rineka Cipta

Arikunto, Suharsimi. 2007. Dasar-dasar evaluasi pendidikan. Jakarta: Bumi Aksara

Djamarah, Syaiful Bahri. 2002. "Psikologi Belajar". Jakarta : PT. Rineka Cipta.

Dimyati, Mujiono. 2006. Belajar dan Pembelajaran. Jakarta: Rineka Cipta.

Fathurrohman dan Wuri Handayani. 2011. Pembelajaran PKn di Sekolah Dasar. Yogyakarta: Nuha Litera.

Hadikusumo, Kunaryo, 1999. Pengantar pendidikan. Semarang: Ikip Semarang Press.

Murti, Jati Krisna. 2009. Penerapan Model Pembelajaran Berbasis Masalah pada Mata Pelajaran PKn untuk Meningkatkan Hasil Belajar Siswa Kelas IV SDN Tirtomarto IV Kecamatan Ampelgading Kabupaten Malang. Tersedia di http://jurnal.ksdp.um.ac.id/index.php/pgsdmalang/article/. Diunduh pada tanggal 30 Juli 2013.

Nur, Muhammad. 2005. "Pembelajaran Kooperatif". Jawa Timur : Depdiknas.

Permendiknas Nomor 22 Tahun 2006 tentang Standar Isi untuk Satuan Pendidikan Dasar dan Menengah. Purwanto, Ngalim1997. Psikologi Pendidikan. Bandung: Remaja Rosdakarya.

Rahayuningtyas, Willis (2011). Penerapan model problem based learning (PBL) untuk meningkatkan motivasi dan hasil belajar siswa pada mata pelajaran PKn kelas V SDN Jatimulyo 1 Kota Malang. Skripsi. Malang: Universitas Negeri Malang

Rusmono. 2012. Strategi Pembelajaran dengan Problem Based Learning itu Perlu. Bogor: Ghalia Indonesia.

Sanjaya, Wina. 2011. Strategi Pembelajaran Berorientasi Standar Proses Pendidikan. Jakarta: Kencana Prenada Media Group.

Saiqudin Hakim, Moh. 2010. Peningkatan Hasil Belajar Siswa Dalam Mata Pelajaran PKn dengan Menerapkan Model Pembelajaran Problem Based Learning $(P B L)$ di SDN. Cerme 2, Kecamatan Pace, Kabupaten Nganjuk. (Tesis). Malang: PPs UM

Sudjana, Nana. 2010. Dasar-Dasar Proses Belajar Mengajar. Bandung: Sinar Baru Algensindo.

Slameto. 2010. Belajar dan Faktor-Faktor yang Mempengaruhinya. Jakarta: Rineka Cipta.

Slavin, Robert. 2009. Cooperatif Learning. Bandung: Nusa Media

Soeparwoto. 2004. Psikologi Perkembangan. Semarang: UNNES Press.

Sugandi, Achmad, 2007, Teori Pembelajaran. Semarang: UNNES Press

-----. Sudjana, Nana. 2002. Penilaian Hasil Proses Belajar Mengajar: Bandung: Remaja Rosdakarya.

Surakhmad, Winarno. 1984. "Pengantar Interaksi Belajar Mengajar: Dasar dan Teknik Metodologi Pengajaran”. Bandung : Tarsito

Suprijono, Agus. 2013. Cooperative Learning. Yogyakarta: Pustaka Pelajar.

Trianto, 2007. Model-Model Pembelajaran Inovatif Berorientasi Konstruktivistik. Jakarta: Prestasi Pustaka.

Tri Anni, Catharina. 2004. Psikologi Belajar. Semarang UNNES Press.

Ubaedillah dan Abdul Rozak. 2010. Pendidikan Kewarganegaraan (Civic Education). Jakarta: Bumi Aksara.

Undang-Undang Republik Indonesia Nomor 20 Tahun 2003 tentang Sistem Pendidikan Nasional. Jakarta: Sinar Grafika.

Undang-Undang Republik Indonesia Nomor 15 tahun 2011 tentang Penyelenggara pemilihan umum

Wena, Made. 2009. Strategi Pembelajaran Inovatif Kontemporer. Jakarta: PT. Bumi Aksara. 